\title{
Bakhtin's mystical organic holism and its consequences for education
}

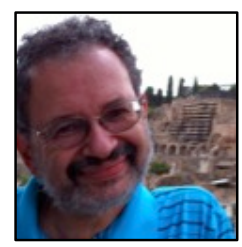

\author{
Eugene Matusov \\ University of Delaware, USA
}

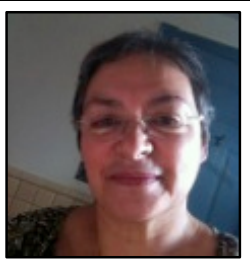

Ana Marjanovic-Shane

Chestnut Hill College, USA

Eugene Matusov is a Professor of Education at the University of Delaware. He studied developmental psychology with Soviet researchers working in the Vygotskian paradigm and worked as a schoolteacher before immigrating to the United States. He uses sociocultural and Bakhtinian dialogic approaches to education. His recent books are: Matusov, E. \& Brobst, J. (2013). Radical experiment in dialogic pedagogy in higher education and its Centauric failure: Chronotopic analysis and Matusov, E. (2009). Journey into dialogic pedagogy.

Ana Marjanovic-Shane is an Associate Professor of Education at Chestnut Hill College in Philadelphia. She studies meaning making in education and play, dialogic educational relationships and events, dialogic teacher orientation, and the role of imagination, drama, play and critical dialogue in education. She uses sociocultural and Bakhtinian dialogic orientation in her studies. Her articles were published by "Mind, Culture, Activity Journal", "Learning, Culture and Social Interaction", and as book chapters in books on play and education. Her most recent publication is: Marjanovic-Shane, A. (2016). "Spoilsport" in Drama in Education vs. Dialogic Pedagogy. Dialogic Pedagogy: An International Online Journal, 4.

$\cos 8080$
"To the grief of all bourgeois
We'll fan a worldwide conflagration, A conflagration drenched in blood - Give us Your blessing, O Lord!
Crowned with a wreath of roses white, Ahead of them - goes Jesus Christ."
"The Twelve", a poem by Alexander Blok (January, 1918) ${ }^{1}$

When I (the first author) read Boris Groys' essay back in 1998, I was shocked. I was reading about Bakhtin flirting with Totalitarianism. My first reaction was denial. I recited many places in Bakhtin that contradict Boris Groys' claims. However, deeply down I knew that Groys pointed at something real and important - something that should not be overlooked. Late, in 2002, when I read Bakhtin's interview

\footnotetext{
${ }^{1}$ Translated by Maria Carlson, http://russiasgreatwar.org/docs/twelve notes.pdf
} 


\title{
Bakhtin's mystical organic holism and its consequences for education
}

Eugene Matusov and Ana Marjanovic-Shane

with Victor Duvakin (Bakhtin, Duvakin, \& Bocharov, 2002), Groys' essay immediately came to my mind. In this interview, Bakhtin bragged about his remote ancestor, who as a Russian aristocrat, rich slave owner, sold many of his slaves to fund one of the first Russian cadet corps. Although this story was contested by Bakhtin's own brother (Bakhtin et al., 2002, pp. 319-320), his neglect of humane values communicated by the story seemed to be rather clear $^{2}$. He praised the Tsarist government for firing many of Russian professors who protested the government's violation of human rights because students should be involved in only one business - i.e., "to study seriously" (Bakhtin et al., 2002, pp. 74-78). Of course, this is only one side of Bakhtin as a person with particular right-wing conservative political values (Bakhtin seemed to sympathize the Russian monarchy and did not approve the February liberal-democratic Revolution of 1917 (Bakhtin et al., 2002, pp. 132-136) ${ }^{3}$ ) but this side did not fit my image of Bakhtin emerging from his literary and philosophical writing. Was Bakhtin little bit like Dostoevsky, who was a very reactionary journalist and a rather monologic public figure but simultaneously a great humanist, dialogist, and polyphonist (Bakhtin, 1999)? Did Bakhtin's political monologism penetrate his philosophy? Boris Groys answers "yes."

Boris Groys charges that in similar veins like Nietzsche before him, Bakhtin was attracted to the Dionysian mystery of the Eros-Thanatos cosmic holism by equating literature to life, embracing violence of carnival, disregarding human privacy, individuality, and dignity, searching for fusion of cosmic voices and forces, and accepting the unified truth, requiring a plurality of consciousnesses that is above an individual consciousness. Groys wrote,

\begin{abstract}
A "polyphonic novel" (Bakhtin, 1999) transcends individual authorship and, therefore, is rooted, according to Bakhtin, in carnival, which refutes all individualization: a "polyphonic novel" is interpreted by Bakhtin as a result of "carnivalization of literature." This means the destruction of the isolation, independence, and individuality of the word and the removal of the author's rights to private discourse diffused in the general polyphony of the language, which belongs collectively to the "people." Bakhtin's theory, in fact, equates literature to life - and, therefore, it invites its reader to see this theory as a life program... At the same time, if there is something Bakhtin insists upon, then it is this totality of carnival, which destroys and absorbs each individual body: for Bakhtin, carnival is first and foremost a manifestation of the belonging to the folk (narodnost'). The belonging to the folk was, by the way, the characteristic core of the Stalinist culture, which followed the period of avant-gardist "belonging to the class" (classovost')) (Groys, DB:3).
\end{abstract}

Bakhtin seemed to deeply distrust human procedures, rules, laws, structures, authority, even if they were produced by liberal democracy, in which the Dionysian carnival does not have a place. Groys argues that Bakhtin despised liberal democracy in the name of the cosmic carnivalistic violent unity,

\footnotetext{
${ }^{2}$ Mikhail Bakhtin, “... my great-great-grandfather... was a brigadier of the Katherine the Great times... I mean he was a brigadiergeneral, ... who specially sacrificed three thousand of his own [slaves'] souls for the creation of one of the first Russian cadet corps. This cadet crops existed until the Revolution." Victor Duvakin, "Did this cadet corps have his name? No?" Bakhtin, "Yes, it did. It was named... the Bakhtin Orlov cadet corps. Even more, for some time, there was also a military cadet school named after Bakhtin. [H]e sacrificed three thousand [slaves'] souls of his own - this was a sort of account. Of course, the [slaves'] souls were not literally sacrificed but they were obviously sold or leased to a bank and so on - as it was done usually then. Back then they counted by [slaves'] souls" (Bakhtin et al., 2002, pp. 19-20, translation from Russian by the first author).

${ }^{3}$ Bakhtin praised Peter Stolypin, a tsarist minister, a monarchist brutally supressing the revolutionary movement in Russia after the Revolution of 1905, "Stolypin was a very big political leader, much bigger than many people imagine, and much more far-sighted. He offered the only correct way to save Russia from the revolution by creation of middle-class rich peasants, economically selfsustained farmers [khutorian], with their own property, small property. He thought that only private property makes a person reliable and... stable. But it didn't work because he could not finish his reform of creation of self-sustained farmers" (Bakhtin et al., 2002, p. 136, translation from Russian by the first author) [Stolypin was assassinated by a revolutionary in 1911], https://en.wikipedia.org/wiki/Pyotr_Stolypin.
}

Dialogic Pedagogy: An International Online Journal | http://dpj.pitt.edu DOI: 10.5195/dpj.2017.222 | Vol. 5 (2017) 


\title{
Bakhtin's mystical organic holism and its consequences for education
}

Eugene Matusov and Ana Marjanovic-Shane

\begin{abstract}
Bakhtin's attitude to liberalism and democracy in their traditional meaning is that of deep antipathy: for him, they are synonymous to alienation, autonomization, clamming up of individuality, the separation of the latter from the natural unity of cosmic and people's life - and, consequently, they become the historical reasons for the emergence of the pathos of seriousness, sentimentality, moralizing, and, also, of the devolution of the people's carnivalesque laughter into individualistic criticism and satire. It is in jubilant expressions that Bakhtin refers to the Rabelaisian descriptions of atrocious carnival battles, stoning people with "funny matter" (feces) and splashing them with urine, the rituals of carnival insults, "dethroning and crowning," the images of the triumphal carnivalesque Death, symbolizing people's joy about the "demise of everything obsolete and already dead."

Bakhtin welcomes the carnivalesque pathos of the "final death" of everything individual and the victory of the purely material, bodily principle over everything transcendental, ideal, individually immortal. Simply put, Bakhtin's carnival is horrible - God forbid being part of it. There is no place for democracy in it - nobody is given the democratic right to avoid the total carnival duty, to abscond the carnival, to stay away from it. On the contrary, those who try to do so are the first to be subjected to "funny insults and beatings." All this grotesque horror, according to Bakhtin, turns into a joyful carnival thanks to people's continuous laughter, by which it is surrounded (DB:3).
\end{abstract}

Was Bakhtin a totalitarian, a crypto-Stalinist? Groys answers, "no," but Groys stops short of qualifying who Bakhtin was beyond saying that Bakhtin was neither totalitarian nor anti-totalitarian. Groys argues that Bakhtin developed cosmic aesthetic of life to address the historical and personal tragic events, "The tragedy of Revolution - and his own personal tragedy - was understood by Bakhtin as a manifestation of the eternal cosmic tragedy, constantly and ritualistically replaying itself, which can and must be "aesthetically justified," in order not to be futile" (DB:4).

We agree with Groys that Bakhtin was neither totalitarian nor anti-totalitarian but rather he subscribed to the Mystical Collective Organic Cosmic Holism existed in his zeitgeist. Many thinkers of his time - such Russian poet Alexander Blok quoted in our epigraph, German philosopher Fredrick Nietzsche, German philosopher of existentialism Martin Heidegger, French existentialist Jean Paul Sartre among many other intellectuals of the first part of the 20th century, - subscribed to the Mystical Collective Organic Cosmic Whole. In contrast to the Totalitarianism, the Mystical Collective Organic Cosmic Holism denies an ideological imposition of one idea - it believes that one consciousness can only sense but can never grasp the Mystical Collective Organic Cosmic Whole, "Not the ascent of the individual soul into the higher sphere but the movement forward of all mankind, along the horizontal of historic time, becomes the basic criterion of all evaluations. Having done its part upon earth, the individual soul fades and dies together with the individual body; but the body of the people and of mankind, fertilized by the dead, is eternally renewed and moves forever forward along the historic path of progress" (Bakhtin, 1984, p. 404). One can only trust and then willingly surrender to this Whole to become one with It, "It should be pointed out that the single and unified consciousness is by no means an inevitable consequence of the concept of a unified truth. It is quite possible to imagine and postulate a unified truth that requires a plurality of consciousnesses, one that cannot in principle be fitted into the bounds of a single consciousness, one that is, so to speak, by its very nature full of event potential and is born at a point of contact among various consciousnesses" (Bakhtin, 1999, p. 81). We suspect that not only the Communist Revolution, Civil War, Bakhtin's own illness, but also his exile, his Christianity, and Stalinist purges probably contributed to Bakhtin's the Mystical Collective Organic Cosmic Holism.

However, we argue that Bakhtin cannot and should not be reduced only to his Mystical Collective Organic Cosmic Holism. At least, there is another, opposing side in Bakhtin, denying the Mystical Collective Organic Cosmic Holism, and focusing on respect for an individual person, human dignity, 


\title{
Bakhtin's mystical organic holism and its consequences for education
}

Eugene Matusov and Ana Marjanovic-Shane

responsibility, Dialogue, postupok (i.e., ethic deed), non-alibi-in-being, unfinalizability, boundary, unmerging, principle opaqueness of consciousnesses, equal rights of consciousness, internally persuasive discourse, prioritization of pravda-truth over istina-truth, interaddressivity, and so on. The other Bakhtin denied the mysticism of supra-consciousness. We do not know if Boris Groys agrees with us about the co-existence of another, humane, Bakhtin or not.

In our view, the Mystical Collective Organic Cosmic Holism can be useful for polyphonic novel where hero-ideas are brought in collision with a carnivalistic plot by the author to let them test their pravda-truths with their life (and death). Thus Bakhtin argued,

\begin{abstract}
The following conclusion can now be drawn. We have uncovered in the menippea [i.e., carnivalistic genre in literature - the authors] a striking combination of what would seem to be absolutely heterogeneous and incompatible elements: philosophical dialogue, adventure and fantasticality, slum naturalism, Utopia, and so forth. We can now say that the clamping principle that bound all these heterogeneous elements into the organic whole of a genre, a principle of extraordinary strength and tenacity, was carnival and a carnival sense of the world (Bakhtin, 1999, p. 134).
\end{abstract}

However, this principle becomes very problematic in the life and especially in education. What can be a creative, aesthetically smart, plot turn in a make-belief novel (e.g., killing the father in Brothers Karamazov) is a horrible crime in real life. In the polyphonic life, a demand for the idea-postupok integrity is possible but rarely achievable or sustainable (and always contested). In the polyphonic education ${ }^{4}$, when beliefs, commitments, and the life itself are suspended, any idea (and its underlining value) can be legitimately examined and deconstructed. While in art, disbeliefs are suspended, in education, beliefs are suspended (Marjanovic-Shane, 2016). In education, ideas have to become detached from the participants - the people's dear ideas can be deconstructed but not people, themselves (in contrast to polyphonic novels). The polyphonic education, rooted in internally persuasive deconstructive discourse (i.e., Big Dialogue), frees people from the tyranny of their dear ideas that colonize them - it follows neither rationalistic, atomistic, individualist Apollo nor orgiastic, cosmic, collectivist Dionysus.

An important question for us, educationalists, emerging from Boris Groys' provocative claim of Bakhtin's Mystical Collective Organic Holism, is whether it affects Bakhtinian approaches in education and if so, how. In our view, the answer is positive - the influences of Mystical Collective Organic Holism seem to be present. So far, we have noticed at least 3 areas, where the Bakhtinian Mystical Collective Organic Holism may penetrate Bakhtinian approaches to education. The first area is application of Bakhtin's notion of a hands-off carnival in education. The second area, also influenced by Socrates, is forceful engaging students in critical examination of their lives by raising "ultimate questions on life and death" (p. 144) "at the threshold of great [life] internal decisions and crises" (Bakhtin, 1999, p. 62) by promoting existential crises in the students. The third area is a claim that in polyphonic education, the teacher-student relations are akin to the author-character relations in a polyphonic novel - the polyphonic teacher is an author of his/her students, who are viewed as "heroes" of the teacher-orchestrated dialogue.

\footnotetext{
4 "Slightly paraphrasing Morson and Emerson's (1990, p. 234) definition of Bakhtin's notion of polyphony, we can define polyphonic classroom, as 'two closely related criteria are constitutive of polyphony: 1) a dialogic sense of truth and 2) a special position of the [teacher] necessary for [promoting] this sense of truth [in the classroom community]. In fact, these two criteria are aspects of the same phenomenon, the polyphonic [classroom's] 'form-shaping ideology'”' (Matusov, 2009, p. 286).
} 


\section{Education as a hands-off carnival}

American Bakhtinian educationalist Timothy Lensmire, inspired by Bakhtin's notion of carnival (Lensmire, 1994b), conducted a pedagogical experiment in a third grade classroom, specifically in his writing workshop, to promote the students' voices through 'private projects" and students' active participation in the world (Lensmire, 1994a, p. 13). The purpose of the workshop was to address alienation and meaninglessness of students' writing in conventional school by promoting students' authorial writing,

In my classroom, I wanted students to come to voice, in both the sense of a private exploration and ordering of experience in the expression of a unique self, and the sense of greater public participation in the cultural work of naming and renaming the world and their places within it. Both senses of voice suggest resistance the first resistance to Dewey's "crust of convention," the second to power relations that silence. ...

My classroom, like Dostoevsky's novels, would celebrate heteroglossia: unofficial voices, the polyphonic confusion of voices sounding with the characteristic words and intonations of different social groups, and the idiosyncratic twists of speakers and writers attempting to force shared, given words to individual, particular purposes and situations (Pechey, 1986; Bakhtin, 1981)....

My role as the teacher was to encourage, orchestrate, and support this heteroglossia, finding ways to help each student sound and be heard (Lensmire, 1994a, p. 14)

The workshop involved three parts. The first 10-min part was whole class brainstorming. The second 30-min part autonomous writing on whatever meaningful was for the students. The third 10-min was sharing time, where the students publicized their texts to the entire class to get their responses and feedback.

With reference to Bakhtin, the teacher, Timothy Lensmire, tried to reduce, if not entirely eliminate, his vertical power, vertical violence, the teacher-student hierarchy in his workshop to create horizontal relations (p.41). In a spirit of Bakhtin's carnival, Lensmire wanted, "a playful, familiar relation to the world" (Lensmire, 1994b, p. 375). Despite this commitment to the horizontal relations, the teacher felt legitimate to force children to write even when they did not want. However, what they could write was completely up to them. With encouragement from the teacher, the students started using their half-fictional, half-true humorous writing as a weapon for scoring their interpersonal conflicts and dramas by soliciting laughter targeting their victims from their peer audience.

Initially, the teacher was pretty satisfied with his pedagogical experiment, noticing how authentic, meaningful, and real the children's writing became - they were writing what was important for them, their writing was directed at real audience, the audience responses shaped by the audience. Children's heteroglossic texts "had very 'social' origins (beyond social origins in shared language, conceptions of story and particular genres, etc.)" (Lensmire, 1994a, p. 49). Lensmire argues that, "The dialogically agitated environment of our writing workshop was a site of struggle over identity, participation, meaning, and values. In their talk and texts, children took up conflicting positions on questions of who should tell whose stories, who should speak and be listened to, whose interpretations are valid, how it is we should treat one another" (Lensmire, 1994a, p. 139). Inspired by Bakhtin, Lensmire also liked "carnival abuse or profanation, and that is expressed ... in the loud blasphemies, obscenities, and parodies that sound in the carnival square" (Lensmire, 1994b, p. 375) that was also evident in his children's writing. 
However, after a while, the teacher noticed that the children's stories generated a lot of laughter in many children but not in all. Even more, the targets of the humorous stories often involved unpopular, marginalized, children (e.g., minorities, physically weak, unattractive, low SES). The stories themselves were strategically hurtful and involved a lot of sexism, sexual exploits, classism, and even racism. Thus, two girls, victims of the stories, noticed the powerful trope of producing peer carnivalesque laughter, "one way to tease a classmate was to name him or her in a story, and then to link the person to someone of the other sex" (Lensmire, 1994a, p. 53). This "upside down" carnivalesque trope is very similar to one described by Bakhtin, "the carnivalistic logic of 'a world upside down': an emperor in the nether world becomes a slave, a slave an emperor, and so forth. The carnivalized nether world of the menippea determined the medieval tradition of representations of joyful hell, a tradition which found its culmination in Rabelais... behind almost all scenes and events of real life, most of which are portrayed in a naturalistic manner, there glimmers more or less distinctly the carnival square with its specific carnivalistic logic of familiar contacts, mésalliances, disguises and mystifications, contrasting paired images, scandals, crownings/decrownings, and so forth" (Bakhtin, 1999, p. 133).

The vertical, institutionally sanctioned, teacher-student relationship became broken, "Through student selection of topics, the child makes the first move in an interaction that places the teacher, ideally, in the position of response. ...workshop approaches also break a teacher dominated discourse by allowing and encouraging children to turn away from the teacher, front and center, to each other. In place of a traditionally unauthentic, fault-finding teacher-audience, workshops promote an authentic, meaningfinding one, and peers are a significant part of that audience" (Lensmire, 1994a, pp. 139-140). However, the vertical power hierarchy and vertical coercion by the teacher was replaced by horizontal power and coercion by the "popular" children and the mainstream oppressive culture behind those "popular" children. At the end of the book, Lensmire formulates his lesson from his pedagogical experiment, criticizing his laissez-faire pedagogical approach, promoting students' carnivalesque meaningful writing,

\begin{abstract}
My stories of [my students at the writing workshop], were stories about textual power put to various ends. One moral of those stories is that teachers must participate in shaping the ends toward which textual power is put by children. A laissez-faire attitude may very well allow status and power differences from the playground and society to assert themselves in the official work of the writing workshop. Children who are still learning about the consequences of their actions may hurt themselves and others in the process. Teacher response to children's texts is one way to influence the ends of children's textual power. Another is through collective writing projects (Lensmire, 1994a, p. 150).
\end{abstract}

Bakhtin's carnival is not necessarily liberating. While, it can be liberating from the vertical oppression by the officialdom as Bakhtin pointed out, it can be even more oppressive by the horizontal informal peer power of the dominate culture ${ }^{5}$. We agree with Lensmire concluding that critical dialogue promoted by the teacher is absolutely necessary, "critical work with the content, the messages of texts" (Lensmire, 1994a, p. 151). It is interesting that Lensmire insisted that his workshop did not live to the promise and potential of Bakhtin's carnival, "...I must immediately admit that if workshop is carnival, it is a rather pale, subdued one--a carnival without bite, without the critical, radical edge of Bakhtin's carnival. In the following section, I contrast workshops to carnival" (Lensmire, 1994b, pp. 379-380). In our view, Lensmire overlooked that Bakhtin insisted on the critical nature of carnival, directed only against the vertical oppression of the officialdom. However, Bakhtin did not consider the horizontal oppression,

${ }^{5}$ William Golding's fictional novel "The lord of flies" is a good illustration of the horizontal power, horizontal oppression, and horizontal violence (Golding, 1999).

Dialogic Pedagogy: An International Online Journal | http://dpj.pitt.edu DOI: 10.5195/dpj.2017.222 | Vol. 5 (2017) 


\title{
Bakhtin's mystical organic holism and its consequences for education
}

Eugene Matusov and Ana Marjanovic-Shane

existing in dominant informal culture, and its relationship with carnival. We argue that Lensmire's workshop was a clear realization of the Bakhtinian carnival in an educational context and not a deviation from it. Lensmire also seemed to overlook the students' critical carnivalesque resistance of the teachers' impositions by at times caricaturing what the teachers wanted from them in his workshop.

This inherent problem of horizontal oppression by carnival caused by the dominant informal culture adds another critical aspect to Boris Groys' argument against Bakhtin's Mystical Collective Organic Holism in addition to Groys' critique of violation of personal dignity, privacy, and freedoms in a Bakhtinian carnival.

\section{Forcing students into dialogue on the threshold}

Bakhtin insisted that a polyphonic novel has to involve "dialogue on the threshold" of people facing their "ultimate questions" when they are faced with existential life and death crises,

\begin{abstract}
...for in fact Dostoevsky always represents a person on the threshold of a final decision, at a moment of crisis, at an unfinalizable-and unpredeterminate-turning point for his soul (p. 61).

...The great dialogue in Dostoevsky is organized as an unclosed whole of life itself, life poised on the threshold.

...The menippea is a genre of "ultimate questions." In it[s] ultimate philosophical positions are put to the test. The menippea strives to provide, as it were, the ultimate and decisive words and acts of a person, each of which contains the whole man, the whole of his life in its entirety. (p. 115)

... Everywhere one meets the stripped-down pro et contra of life's ultimate questions (Bakhtin, 1999, p. 116).
\end{abstract}

Inspired by Bakhtin's notion of "dialogue on the threshold" in a polyphonic novel and by Socrates' insistence that "the unexamined life is not worth living," educationalist Eugene Matusov (the first author) redefined education as forceful engagement of the students in a critical dialogue "at the threshold of great [life] internal decisions and crises" (Bakhtin, 1999, p. 62) by promoting their existential crises (Matusov \& Brobst, 2013).

Matusov observed in his graduate seminar for future doctoral educational researchers that they were reluctant to participate in his assignments despite the fact they found these learning activities very useful for their professional and personal development (Matusov \& Brobst, 2013). In his pedagogical experiment, he abandoned enforcing his assignments, making these assignments suggestive and voluntary - the learning activities were highly recommended by the professor but it was up to the students to do them (no negative consequences would be imposed). Immediately, his students stopped preparing for the class meetings. Their participation was reduced to their attendance and engagement in the class online forum. On the class forum, Matusov challenged the students by asking the students when they were engaging in the academic activities on their own initiatives. It turned out that the students felt ownership for their own academic activities only within confines of some assignments, enforced by their professors, but never initiated their own educational activities, despite having their own strong interests. The critical dialogue about their learning habits, pursued by Matusov, quickly escalated to the existential questions posed to the students about the purpose of their education, its place in their lives, and, ultimately, about their lives itself. Matusov insisted that the students should answer these "ultimate," "internally penetrating" (Bakhtin, 1999), "stinging torpedo touch questions" (Plato \& Bluck, 1961) to themselves and not to him. This led the students to deep existential crises, they could not resolve. They 


\section{Bakhtin's mystical organic holism and its consequences for education}

Eugene Matusov and Ana Marjanovic-Shane

could not stop thinking about these questions, could not stop participating on the class forum replying to the professor, and some even stopped sleeping. The polyphonic education, deeply engaging the students' subjectivities and ontologies, seemed to be flourishing in the truly Bakhtinian spirit.

However, Matusov had felt then and later reflected in his book (Matusov \& Brobst, 2013) that he overstepped his role by arrogantly assuming "God's position" or a position of an author of a polyphonic novel, confusing literature and art. This accusation was also directed against Socrates and the Socratic method for illegitimate messing up with the students' lives (Rud, 1997).

Knowledge can be painful. Some educators view pain of knowledge as a desirable instruction for students' intellectual and personal growth. This new knowledge (new epistemological vista, new paradigm) can undermine one's existing comfort, one's existing ontology, one's existing being, and even one's existing well-being. Consider, for example, Socrates' notion of "torpedo touch", as one of the most sophisticated pedagogical violence that was described:

Meno: If I may venture to make a jest upon you, you seem to me both in your appearance and in your power over others to be very like the flat torpedo fish, who torpifies those who come near him and touch him, as you have now torpified me, I think. (Plato \& Jowett, 1937)

We call the pain that Socrates caused by creating disorientation in the student "epistemological pain." This pain is very real. The question is whether epistemological violence, promoted by the teacher against the students in the name of critical examination of the students' own life, legitimate in education? Matusov's student, Michele (a pseudonym) a participant of his pedagogical experiment who experienced epistemological pain caused by her professor Matusov, strongly disagrees (in a year after Matusov's pedagogical experiment was over),

Michele: i guess it [this critical dialogue] becomes obsessive such that it interferes with other aspects of life... i dunno [Eugene], it's so weird and hard to explain but it feels like a ball and chain like a drug or an addiction or something... maybe it's just me though? maybe i'm too sensitive? like with my lack of community behind and other [personal] issues i have in my life... [these internal dialogues prompted by Eugene are] like all related to all this stuff... it's all so very penetrating... excuse the French, but it's like a mindfuck. because maybe it does conflate with personal issues i have, but i'm sure other people have similar issues, so some of your other students could have or could be suffering like me.... but i'm sure it's worse on grad students than undergrads... i think you are very good at asking very important and penetrating questions... and sometimes you can get people to question their existence or their ways of living or why they're doing what they're doing, etc etc... you have that blessing that is a curse maybe...

Edward [i.e., Eugene]: Of course, by now you can imagine me asking, "What is wrong with that -i.e., asking about life?"...

Michele: because i wonder if you could question someone to despair or death? (Matusov \& Brobst, 2013, p. 82).

Other type of pedagogical pain may involve intentional humiliation to promote desired learning in a student. For example, in accordance to this Socratic pedagogical method, a famous US educator Jane Elliott humiliates a White female college student to learn about a systemic problem of racism https://www.youtube.com/watch?v=neEVoFODQOE. The student does not appreciate this learning but 


\section{Bakhtin's mystical organic holism and its consequences for education}

Eugene Matusov and Ana Marjanovic-Shane

her White peers seem to do, despite by the observable pains caused by Elliott in them. In contrast to Matusov, who forcefully threw his students into their existential crises to let them struggle with these crises internally, Elliott wanted to cure her students from racism by her intentional pedagogical use of humiliation. Rud (1997) calls pedagogical use of humiliation as "the dark side" of the Socratic Method, commonly used in teaching law ${ }^{6}$. Although Elliott and the law professors using this Socratic Method are not Bakhtinian educators, they employ the idea rooted in Bakhtin (and Socrates) to throw the students into existential crises and legitimatize the pedagogically-induced pain in education without any student consent. The issue here is NOT the use of humiliation but purposeful pedagogical use of pain without students' consent ${ }^{7}$.

We think that Boris Groys is right that Bakhtin confused literature and life. In literature, it is legitimate for an author of a polyphonic novel to bring his/her heroes to a dialogue on the threshold of their life and death existential crises to test their deep ontological ideas. But for an educator (or anybody else for that matter), it becomes illegitimate and irresponsible playing God with his/her students. We argue that only students (persons) themselves have the right to throw themselves into their own existential crises and question themselves and no one else ${ }^{8}$. The role of a dialogic educator may be to create a safe learning dialogic environment, in which students can explore, experiment, examine, and test diverse possibility without jeopardizing their life and well-being by pushing them into their existential abyss. And, like a good dentist, the dialogic educator may need to warn the students that they may experience existential crises and give them a choice of not to go into them.

\section{Teacher as a Dostoevskian polyphonic novelist}

In their attempts to translate the Bakhtinian polyphonic framework into education, several Bakhtinian educationalists argue that a polyphonic teacher is akin to Dostoevsky as a polyphonic novelist, while students in a polyphonic classroom are akin to the idea-hero characters of Dostoevsky's polyphonic novels. Most notably, this approach has been developed by Timothy Lensmire (1997) and Kiyotaka Miyazaki (Matusov \& Miyazaki, 2014; Miyazaki, 2009). Thus, Lensmire being dissatisfied of his laissezfaire carnivalesque writing workshop, described above, searches for re-introduction and rehabilitation of the teacher authority,

In this article I examine how teaching and the teacher's role in elementary and secondary school writing classes have been conceptualized.... To do this, I develop the metaphor of the writing teacher as Dostoevskian novelist. That is, I imagine the teacher as a novelist who creates a classroom-novel and takes up relations with student-characters. A Dostoevskian novelist, and not some other sort, because of the instructive similarities and differences between the project that Dostoevsky pursued in his novels and the project that workshop advocates want teachers to embrace in the writing classroom. At the heart of these projects and a primary theme of this article is the rejection of traditional relations between novelist and character, teacher and student, and the embrace of new ones. ... Dostoevsky's method of freeing his characters... was based on approaching characters not as objects to be manipulated, but as subjects to be dialogued with.

\footnotetext{
${ }^{6}$ Rud provides a very good illustration of such Socratic Method, based on intentional humiliation of students, in the 1973 movie "The paper chase."

7 Pain and existential crises in a student can be an unfortunate by-product of education that an educator can try to ameliorate, eliminate, and warn about (like a dentist does, while treating a patient). This is a very different from purposeful causing pain and existential crises in the student as instruction and learning (like use of shock therapy in mental health - pain itself as a way of treatment). Under current guidance, the latter can be used only with the consent of the patient.

${ }^{8}$ In a Hungarian fictional novel "The fifth seal," a photographer sent a group of ordinary, "little," people to the Hungarian Gestapo in 1944 , during the terror by the Nazi Hungarian government of Ferenc Szálasi, for them to experience existential crisis and engage in the critical dialogue on the threshold (Fábri, 1976; Sánta, 1986).
} 


\section{Bakhtin's mystical organic holism and its consequences for education}

Eugene Matusov and Ana Marjanovic-Shane

How students' freedom is imagined and achieved in writing workshops is a second important theme in this article.... A third theme is teacher authority and power in the workshop... I argue that students' relative control over their own writing in the workshop is a function of teacher design and power. That is, rather than being antithetical to student freedom, teacher power is necessary to assure it (Lensmire, 1997, pp. 368-369).

With a reference to Bakhtin, Lensmire argues that, "The [polyphonic] novelist's [and thus polyphonic teacher's] power is used to develop, as much as possible, the 'inner logic and independence' of an other's voice and perspective" (Lensmire, 1997, p. 375). Lensmire seems to want to expand the traditional laissez-faire writing workshop, where students have an opportunity to voice their dear interests, tensions, and ideas, however oppressive they can be - "sexist, classiest points of view expressed in student text" (p. 385). After the tensions and oppressions are revealed in the students' texts, Lensmire apparently wants to engage the students in adventurous collisions of their dear ideas to promote the emergence of their critical consciousness,

In order to free student-characters from the stifling restrictions of the traditional school plot, the teacher-as-novelist writes them into an adventure story. Within that story, the student-characters pursue their interests and come to express themselves in a rough-and-tumble mix of people and ideas" (Lensmire, 1997, p. 378).

The workshop functions similarly for the student: In contrast to the traditional classroom plot, the workshop-as-adventure-plot 'connects him and makes him collide with other people under unusual and unexpected conditions' (Bakhtin, 1984a, p. 105). In other words the student's social position, as student, does not exhaust who he is within the workshop, nor does it dictate his interactions with the world and others (Lensmire, 1997, p. 379).

We can expect that pursuing such work with students will make workshop teaching and learning harder, not easier. To examine and call into question important aspects of our identities and worldviews is a complicated and often distressing task. As we make workshops into sites of serious moral and political deliberation as teacher and student questions and reflections focus attention (and sometimes criticism) on meanings and values held dear by workshop participants the work of the writing workshop will become both more meaningful and more difficult and riskier (Lensmire, 1997, p. 389).

However, exactly how the polyphonic teacher has to design the adventure plot among his student-characters that promotes a critical dialogue among them remains very scratchy.

Japanese educationalist Kiyotaka Miyazaki starts where American educationalist Timothy Lensmire ends. Miyazaki unpacks, operationalizes, and further conceptualizes Lensmire's notion of a "teacher as a Dostoevskian polyphonic novelist." He develops a pedagogical example using a teaching literature lesson by a Japanese fourth-grade teacher Yoko Nishioka, inspired by Saitou's pedagogy. Miyazaki shows that the polyphonic novelist teacher's authorship involves developing a drama of ideas using students' contributions and exposing the students to this drama. Students' ideas are characters in the teacher's drama.

Thus, Miyazaki describes an episode of dialogic teaching in a polyphonic classroom in which the teacher designs the dialogic "arena" and then guides her/his student-heroes in testing various ideas about a provocative dialogic problem. The teacher engaged 4th grade students in this episode in an analysis of a folk tale about a mischievous fox and a poor fisherman. In the story, the fox stole the fish that the 


\section{Bakhtin's mystical organic holism and its consequences for education}

Eugene Matusov and Ana Marjanovic-Shane

fisherman caught inadvertently causing the fisherman's old and sick mother to die of starvation. When the fox realized how much his actions hurt the fisherman, the fox decided to nurture the bereaved fisherman by daily gifts fruit and nuts which he secretly left at the fisherman's door. The teacher engaged the students in brainstorming about the fox's motivation for secretly bringing food to the fisherman. The children offered many different explanations and the teacher engaged them to compare and contrast them, to make judgments about their plausibility. In addition, the teacher also strengthened some weaker ideas held by a minority of the students, challenging the dominant positions and leaving the discussion open. In this episode, Miyazaki stresses that the teacher as a polyphonic novelist author designs such a polyphonic classroom by "setting the stage" and "make[ing] children [into] polyphonic heroes" who could generate "their new, unexpected views ... The key for setting the stage is to generate a dialogic problem for children..." (Miyazaki, 2009, p. 8).

The role of the polyphonic novelist teacher should start with advance preparation by developing a smart spider-web of provocations, rooted in the material and in the internal dialogue between the teacher as a critical person of culture and the material. By doing that the teacher makes the taught material exciting, interesting, and problematic for the teacher him/herself. Miyazaki quotes the famous Japanese educator Kihaku Saitou (1911-1981) to describe this process of preparation,

First of all, a teacher should encounter and confront wholeheartedly with the teaching material in all its respects as one person. A teacher should wholeheartedly interact with the teaching material, analyze it, have questions on it, ask himself, discover something, and create something, as one person. Though these endeavors, he should accumulate new thinking, new logic, and new development.

Only after the teacher has done such interpretative works on the teaching material and encountered with it, a lesson can have a definite direction, intention and an explicit construction. It is because the teacher's knowledge about the teaching material stops being a collection of random pieces, but becomes a lively one, acquired by his own, sweaty efforts, only after such encounters. It is because the teacher can confront children with the lively knowledge which he acquired by surprised of it, by doubting it, or by discover it afresh (Saitou 1964) (cited in Miyazaki, 2009, p. 9).

Then, the polyphonic novelist teacher should engage them in a meaningful exchange of ideas, to solicit the students' contributions, to abstract the tensions among these ideas by cleverly revoking them, to make the tensions visible to the students, to ask the students for the resolution of these tensions, and to occasionally challenge the students' ideas, when they cannot challenge these ideas themselves. Miyazaki forcefully argues that, "The [polyphonic novelist] teacher should generate such kind of problems to have a dialogic classroom. It is teacher's responsibility, not children's to discover the dialogic problems in the learning content in front of children. The discovery of the dialogic problem becomes possible by teacher's learning of children's learning content" (Miyazaki, 2009, p. 8). Yes, students can occasionally ask questions but it is the role of the polyphonic novelist teacher to define the problematics of the classroom critical dialogue. Finally, Miyazaki argues that the unity of the polyphonic novelist teacher's dramatic problematics remains open and unfinalized and the critical classroom dialogue remains open to continue.

We respectfully disagree with this vision of teacher as a Dostoevskian polyphonic novelist. We disagree that "the teacher as a person who is responsible for other [students'] learning" (Miyazaki, 2009, p. 4). We believe that the students are most and foremost responsible for their own education and they are the final authority of their own education (Klag, 1994; Matusov, 1999). We think that the teacher's

Dialogic Pedagogy: An International Online Journal | http://dpj.pitt.edu DOI: 10.5195/dpj.2017.222 | Vol. 5 (2017) 


\section{Bakhtin's mystical organic holism and its consequences for education}

Eugene Matusov and Ana Marjanovic-Shane

pedagogical authorship has to be subordinated and to serve to the students' own educational authorship. It is the students' own diverse problematics, which is important and not the teacher's one. Students are not dialogic characters in the polyphonic idea-adventure novel built by the polyphonic novelist teacher. Students are authors of their own polyphonic novels and the main role of the teacher to help them with their own educational authorship. We think that the educational design - curriculum, instruction, class governance, resolving interpersonal relations - has to be open to the students, rather than to be the solo or even primary the domain of the polyphonic novelist teacher's responsibility.

Placing people (e.g., students) as actors or characters of somebody else's play (e.g., novel, classroom) or adventurous drama of ideas is ultimately disrespectful to the human agency. Thus, we respectfully disagree with Timothy Lensmire arguing that, "For the opposing moments of art and education are not, ultimately, opposing" (1997, p. 390). The art and the life (and education) are very different, opposing, and cannot be treated similarly. In novelistic art, the writer ultimately keeps power of creation and design and cannot share it with the characters. When education follows art, the power to design an adventurous drama of ideas, in which the students actively and dialogically participate as characters, promotes the teacher's Mystery, as the ultimate puppeteer, catching the students' subjectivity in the sticky spider-web of provocations, problematization, and adventurous drama of ideas. The teacher's unfolding problematization of the students' contributions creates the Organic Cosmic Holism, rooted in Bakhtin's polyphonic and carnivalesque framework.

In contrast, in genuinely polyphonic education, the teacher should be ultimately dethroned from the position of the almighty and all-comprehensive God, the Wizard, who organizes the intellectual and ontological being of the students. The students should have the authorial power to design their own education. The teacher must serve the students' power.

\section{Conclusions}

We agree with Groys that art, life, and education have to be kept separate - attempts to combine them lead to Holism, if not to Totalitarianism. While art may welcome unity and holism, life may embrace it as temporary and contested moment. Holism in education is deadly and oppressive. Students are not idea-characters of the teacher's polyphonic pedagogical authorship but rather are full-fledged authors of their own education, ideas, and life. Pedagogical responsibility and authorship of the teacher should be aimed at supporting the critical authorship of the students, as the students wish it, - ultimately education cannot be forced. In contrast to art, carnival and/or dialogue on the threshold should not be an alibi for the teacher to throw their students into existential crises or epistemological pains. In literature, a writer can kill characters or dramatize their life to reveal the truth of their ideas. But in life, this would be a condemned crime or, at least, an unethical behavior. Bakhtin's literary dialogic and carnivalistic framework cannot and should not be directly translated into the life and education.

Indeed, for whatever historical and biographical reasons, one of the big ontological attractions for Bakhtin seems to be toward this Mystical, Collective, Organic, Cosmic Holism (Monism). Being one with the Cosmos, being one with the Unity, being one with Cycle of Death and Rebirth, being one with Cosmic Laughter on "Human Comedy" might help Bakhtin to be above the life with all its tragedies, pains, crimes and betrayals. Bakhtin the Conservative, clearly had distrust in the people's ability to govern their own lives. As a consequence, the attraction to Monism made Bakhtin's political and philosophical stance somewhat reactionary, illiberal, undemocratic and in some way even flirting with totalitarianism. We agree with Groys' critique of Bakhtin that 'Bakhtin's attitude to liberalism and democracy in their traditional meaning is that of deep antipathy: for him, they are synonymous to alienation, autonomization, clamming up of individuality, the separation of the latter from the natural unity of cosmic and people's life - and,

Dialogic Pedagogy: An International Online Journal | http://dpj.pitt.edu

DOI: 10.5195/dpj.2017.222 | Vol. 5 (2017)

DB:72 
consequently, they become the historical reasons for the emergence of the pathos of seriousness, sentimentality, moralizing, and, also, of the devolution of the people's carnivalesque laughter into individualistic criticism and satire" (Groys, p. DB:3). Strangely enough, for maybe different reasons, we found attractions to Bakhtin's conservative monistic ontological project among contemporary Bakhtinian Educationalists. Of course, Bakhtin the Conservative was not the only Bakhtin. Another Bakhtin was Bakhtin the Humanist, who criticized Monism, Unity, Mysticism, and disrespect of human agency, as a person-lichnost (not a member of class, classovost, or ethnic people, nardonost).

We want to appeal to the Other Bakhtin, Bakhtin-the-Humanist. The core of Bakhtin-the-Humanist can probably be defined by his insistence on "consciousnesses with equal rights" (Bakhtin, 1999), which means that all participants have the right to be taken seriously regardless their social, institutional, political, epistemological, cultural, or age status. Bakhtin-the-Humanist defined excessive monologism as, "A denial of the equal rights of consciousnesses vis-a-vis truth (understood abstractly and systemically). God can get along without man, but man cannot get along without Him. The teacher and the disciple (Socratic dialogue)" (Bakhtin, 1999, p. 285). Without the teacher's assumption that the student is the final authority for his/her own education, life, ideas, and ontology; without the teacher's respect the student's final authority; without the teacher's acceptance of consciousnesses with equal rights; - genuine polyphonic education is impossible.

\section{References}

Bakhtin, M. M. (1984). Rabelais and his world (H. Iswolsky, Trans. 1st Midland book ed.). Bloomington: Indiana University Press.

Bakhtin, M. M. (1999). Problems of Dostoevsky's poetics (Vol. 8). Minneapolis: University of Minnesota Press.

Bakhtin, M. M., Duvakin, V. D., \& Bocharov, S. G. (2002). M.M. Bakhtin: besedy s VD Duvakinym [M.M. Bakhtin: Conversations with V.D. Duvakin]: Soglasie.

Fábri, Z. (Writer). (1976). The fifth seal [VHS]. In Mafilm (Producer). Hungry: Facets Video.

Golding, W. (1999). Lord of the flies: A novel. New York: Penguin.

Klag, P. (1994). A new look at Invitational Education. The Collaborator, 5(14), 1-2.

Lensmire, T. J. (1994a). When children write: Critical re-visions of the writing workshop. New York: Teacher College Press.

Lensmire, T. J. (1994b). Writing workshop as carnival: Reflections on an alternative learning environment. Harvard Educational Review, 64(4), 371-391.

Lensmire, T. J. (1997). The teacher as Dostoevskian novelist. Research in the Teaching of English, 31(3), 367-392.

Marjanovic-Shane, A. (2016). "Spoilsport" in drama education vs. dialogic pedagogy. Dialogic Pedagogy: An International Online Journal, 4, A45-A80. Retrieved from http://dpj.pitt.edu/ojs/index.php/dpj1/article/view/151/113 doi:10.5195/dpj.2016.151

Matusov, E. (1999). How Does a Community of Learners Maintain Itself? Ecology of an Innovative School. Anthropology \& Education Quarterly, 30(2), 161-186.

Matusov, E. (2009). Journey into dialogic pedagogy. Hauppauge, NY: Nova Science Publishers. 


\section{Bakhtin's mystical organic holism and its consequences for education}

Eugene Matusov and Ana Marjanovic-Shane

Matusov, E., \& Brobst, J. (2013). Radical experiment in dialogic pedagogy in higher education and its centaur failure: Chronotopic analysis. Hauppauge, NY: Nova Science Publishers.

Matusov, E., \& Miyazaki, K. (2014). Dialogue on dialogic pedagogy. Dialogic Pedagogy: An International Online Journal, 2, SI:ddp-1 - SI:ddp-47. doi:10.5195/dpj.2014.121

Miyazaki, K. (2009). Teacher as the author of polyphonic novel: Bakhtinian analysis of a Japanese view on dialogic education. Paper presented at the 2nd International Interdisciplinary Conference on Perspectives and Limits of Dialogism in Mikhail Bakhtin, Stockholm University, Sweden.

Morson, G. S., \& Emerson, C. (1990). Mikhail Bakhtin: Creation of a prosaics. Stanford, CA: Stanford University Press.

Plato, \& Bluck, R. S. (1961). Meno. Cambridge, UK: University Press.

Plato, \& Jowett, B. (1937). The dialogues of Plato. New York,: Random House.

Rud, A. G. (1997). The use and abuse of Socrates in present day teaching. Education Policy Analysis Archives, 5(20), available: http://epaa.asu.edu/epaa/v5n20.html.

Sánta, F. (1986). The fifth seal: A novel (A. Tezla, Trans.). Budapest: Corvina.

\section{(c)) EY}

New articles in this journal are licensed under a Creative Commons Attribution 4.0 United States License.

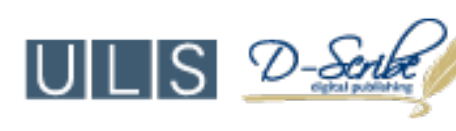

This journal is published by the University Library System, University of Pittsburgh as part of its D-Scribe Digital Publishing Program and is cosponsored by the University of Pittsburgh Press. 